brazilianpoliticalsciencereview

B O O K R E V I E W

\title{
Destined for War: Can America and China Escape Thucydides's Trap?*
}

\author{
by Hugo Bras Martins da Costa ${ }^{\dagger}$ \\ ${ }^{\dagger}$ Universidade Estadual do Rio de Janeiro, Rio de Janeiro, Rio de Janeiro, Brazil
}

(Allison, Graham. Destined for War: Can America and China Escape Thucydides's Trap?

New York: Houghton Mifflin Harcourt, 2017)

What is 'Destined for War's' main argument? In sum, the impact of a rising China on the United States and the global order under American hegemony are leading these two nations toward an avoidable violent clash, which neither one wants, because they risk falling into what the author calls "Thucydides's Trap".

In the introductory chapter, Thucydides's Trap is described by Allison (2017) as a dangerous dynamic that occurs when a rising power threatens to displace a ruling power or to challenge its hegemony. That dynamic creates structural conditions of severe stress (rising power syndrome ${ }^{1}$, ruling power syndrome ${ }^{2}$ and transitional friction ${ }^{3}$ ) in which, intentions aside, not only unexpected events by third parties or accidents that would otherwise be inconsequential or manageable, but even ordinary flashpoints in foreign affairs, can act as sparks that trigger large-scale conflict. Methodologically, the dependent variable of the analytical framework of Thucydides's Trap is a dummy variable -

(*) DOI: http://dx.doi.org/10.1590/1981-3821201800030008

This publication is registered under a CC-BY Licence.

${ }^{1}$ The "rising power syndrome" highlights a rising state's enhanced sense of itself, its interests, and its entitlement to recognition and respect. A growing sense of self-importance (my voice counts) leads to an expectation of recognition and respect (listen to what I have to say) and a demand for increased impact (I insist).

${ }^{2}$ The "ruling power syndrome" is essentially the established power exhibiting an enlarged sense of fear and insecurity as it faces intimidations of decline. The established power views the upstart's assertiveness as disrespectful, ungrateful, and even provocative or dangerous.

${ }^{3}$ In this dynamic, rising powers typically believe institutions are not changing fast enough, and see delay as evidence that the established state is determined to contain it. Ruling power believe the rising state is overreaching in demanding more rapid adjustments than are either merited or safe. 
war or not war between the rising power and the ruling power - which is the outcome of two independent variables. These are: firstly, the objective conditions surrounding the emergence of the rising power relative to the ruling power; and, secondly, the subjective conditions, which is the perception of the rising power, especially by the ruling power.

Throughout part one (The rise of China), Allison (2017) draws the reader's attention to the size, speed and scale of China's rise that, in just a single generation, has emerged like a rocket to displace the United States as number one in many areas. As a consequence of this rise, the author stresses that Chinese leaders have become unsatisfied with the inherited world order designed by the US in the aftermath of World War II, thus having deployed a clearly revisionist strategy. In this regard, he points out that through the use of hard instruments of soft power and economic instruments (from trade and investment policy to sanctions, cyberattacks, and foreign aid) to achieve geopolitical goals, China is spreading its economic network across the globe, altering the international balance of power in a way that causes even longtime United States allies in Asia to tilt from the US toward China.

In part two (Lesson from history), Allison (2017) reviews the records of 16 cases in which an ascending power challenged an established power in the past five hundred years (Table 01) in order to argue that, in such background conditions, war is the most likely outcome (12/16 cases) but not an inevitable one (4/16 cases). According to him, with huge and painful adjustments in attitudes and actions on the part of challenger and challenged alike, the major ruling powers can manage relations with rivals, even those that threaten to overtake them, without triggering a war.

In part two (Lesson from history), Allison (2017) reviews the records of 16 cases in which an ascending power challenged an established power in the past five hundred years (Table 01) in order to argue that, in such background conditions, war is the most likely outcome (12/16 cases) but not an inevitable one (4/16 cases). According to him, with huge and painful adjustments in attitudes and actions on the part of challenger and challenged alike, the major ruling powers can manage relations with rivals, even those that threaten to overtake them, without triggering a war.

Through part three (A gathering storm), the author describes China's Grand Strategy. He points out that it is based on four main national goals: returning China to the predominance in Asia it enjoyed before the West intruded; reestablishing control over the territories of 'Greater China', including not just Xinjiang and Tibet on the mainland, but also Hong Kong and Taiwan; recovering its historic sphere of influence along its borders and in the adjacent seas so that others give it the deference great nations have always demanded; commanding the respect of other great powers in the councils of the world. 
Table 1: Thucydides's Trap Case File

\begin{tabular}{|c|c|c|c|c|c|}
\hline № & Period & Rulling Power & Rising Power & Domain & Result \\
\hline 1 & Late 15 th century & Portugal & Spain & $\begin{array}{l}\text { Global empire and } \\
\text { trade }\end{array}$ & No War \\
\hline 2 & First half of 16th & France & Hapsburgs & $\begin{array}{l}\text { Land power in } \\
\text { western Europe }\end{array}$ & War \\
\hline 3 & $\begin{array}{l}16 \text { th and } 17 \text { th } \\
\text { centuries }\end{array}$ & Hapsburgs & Ottoman Empire & $\begin{array}{l}\text { Land power in central } \\
\text { and eastern Europe, } \\
\text { sea power in the } \\
\text { Mediterranean }\end{array}$ & War \\
\hline 4 & $\begin{array}{l}\text { First half of } 17 \text { th } \\
\text { century }\end{array}$ & Hapsburgs & Sweden & $\begin{array}{l}\text { Land and sea power } \\
\text { in nothern Europe }\end{array}$ & War \\
\hline 5 & $\begin{array}{l}\text { Mid-to-late 17th } \\
\text { century }\end{array}$ & Dutch Republic & England & $\begin{array}{l}\text { Global empire, sea } \\
\text { power and trade }\end{array}$ & War \\
\hline 6 & $\begin{array}{l}\text { Late } 17 \text { th to mid-18th } \\
\text { centuries }\end{array}$ & France & Great Britain & $\begin{array}{l}\text { Global empire and } \\
\text { European land power }\end{array}$ & War \\
\hline 7 & $\begin{array}{l}\text { Late } 18 \text { th and early } \\
\text { 19th centuries }\end{array}$ & United Kingdom & France & $\begin{array}{l}\text { Land and sea power } \\
\text { in Europe }\end{array}$ & War \\
\hline 8 & Mid-19th century & $\begin{array}{l}\text { France and United } \\
\text { Kingdom }\end{array}$ & Russia & $\begin{array}{l}\text { Global empire, } \\
\text { influence in Central } \\
\text { Asia and eastern } \\
\text { Mediterranean }\end{array}$ & War \\
\hline 9 & Mid-19th century & France & Germany & $\begin{array}{l}\text { Land power in } \\
\text { Europe }\end{array}$ & War \\
\hline 10 & $\begin{array}{l}\text { Late } 19 \text { th and early } \\
\text { 20th centuries }\end{array}$ & China and Russia & Japan & $\begin{array}{l}\text { Land and sea power } \\
\text { in East Asia }\end{array}$ & War \\
\hline 11 & Early-20th century & United Kingdom & United States & $\begin{array}{l}\text { Global economic } \\
\text { dominance and naval } \\
\text { supremacy in the } \\
\text { Western Hemisphere }\end{array}$ & No War \\
\hline 12 & Early-20th century & $\begin{array}{l}\text { United Kingdom } \\
\text { suported by France } \\
\text { and Russia }\end{array}$ & Germany & $\begin{array}{l}\text { Land power in } \\
\text { Europe and global sea } \\
\text { power }\end{array}$ & War \\
\hline 13 & Mid-20th century & $\begin{array}{l}\text { Soviet Union, France, } \\
\text { United Kingdom }\end{array}$ & Germany & $\begin{array}{l}\text { Land and sea power } \\
\text { in Europe }\end{array}$ & War \\
\hline 14 & Mid-20th century & United States & Japan & $\begin{array}{l}\text { Sea power and } \\
\text { influence in the } \\
\text { Asia-Pacific region }\end{array}$ & War \\
\hline 15 & 1940s-1980s & United States & Soviet Union & Global power & No War \\
\hline 16 & 1990s-present & $\begin{array}{l}\text { United Kingdom and } \\
\text { France }\end{array}$ & Germany & $\begin{array}{l}\text { Political Influence in } \\
\text { Europe }\end{array}$ & No War \\
\hline
\end{tabular}

Source: Allison, 2017, p.42. 
He also describes the agenda of action of the Chinese government in order to achieve this aims: revitalizing the Party, cleansing its corruption, restoring its sense of mission, and reestablishing its authority in the eyes of the Chinese people; reviving Chinese nationalism and patriotism to instill pride in being Chinese; engineering a third economic revolution; reorganizing and rebuilding China's military so that it can 'fight and win'.

Moreover, Allison (2017) resurrects Samuel Huntington's classical thesis of Clash of Civilizations ${ }^{4}$. He argues that, as China pursues its objectives, deep cultural differences (Table 02), which are entirely independent of the structural stress of Thucydides's Trap, not only exacerbate its rivalry with the United States, but also tend to make US-China relations much harder to manage because they will not respond in the same way to identical provocations.

Table 2: America and China clash of cultures

\begin{tabular}{lll}
\hline & America & China \\
\hline Self-perception & 'Number one' & 'Center of the universe' \\
Core value & Freedom & Order \\
View of government & Necessary evil & Necessary good \\
Form of government & Democratic Republic & Responsive authoritarianism \\
Exemplar & Missionary & Inimitable \\
Foreigners & Inclusive & Exclusive \\
Time horizon & Now & Eternity \\
Change & Invention & Restoration and evolution \\
Foreign policy & International order & Harmonious hierarchy \\
\hline
\end{tabular}

Source: Allison, 2017, p.141.

The author concludes the third part of the book by presenting numerous scenarios in which the underlying stress produced by China's disruptive rise creates conditions in which accidental, otherwise inconsequential events, could trigger a large-scale conflict: an accidental collision at the South China Sea; Taiwan moving toward independence; confrontation with or between third party allies; North Korean collapse; economic conflict. However, he certainly presents the South China Sea as the great point of tension between US and China today.

In part four (Why war is not inevitable), Allison (2017) analyses the four historical cases in which rising and ruling powers successfully steered their ships of state through treacherous shoals without war. According to him, these cases offer twelve clues for US leaders seeking to make the rise of China a case of no war: 01. higher authorities can help resolve rivalry without war; 02. states can be embedded in larger economic, political and security institutions

\footnotetext{
${ }^{4}$ According to Huntington thesis of Clash of Civilization, in a globalized world, civilizational differences are growing more, not less, significant as sources of conflict that could shape not only the future diplomacy but also the course of war.
} 
that constrain historically 'normal' behaviors; 03. wily statesmen make a virtue of necessity — and distinguish needs and wants; 04. timing is crucial; 05. cultural commonalities can help prevent conflict; 06. there is nothing new under the sun- except nuclear weapons; 07. 'mutual assured destruction' really does make all-out war madness; 08. hot war between nuclear superpowers is thus no longer a justifiable option; 09. leaders of nuclear superpowers must nonetheless be prepared to risk a war they cannot win; 10. thick economic interdependence raises the cost - and thus lowers the likelihood $\rho$ - of war; 11 . alliances can be a fatal attraction; 12. domestic performance is decisive.

Furthermore, the author argues that the strategy of 'engage but hedge' that the United States has followed to China under both Republican and Democratic since the end of the Cold War is fundamentally a contradiction. Bureaucratically, this doctrine has allowed each government department to follow its natural inclinations. While the Departments of State and Treasury 'engage', the Department of Defense and intelligence community 'hedge'. He also points out two fatally flawed assumptions of this Strategy: that China will become a democracy or a responsible stakeholder in the US world order, following the footsteps of Germany and Japan in the aftermath of World War II.

In this regard, Allison (2017) concludes the fourth part of the book with four potential strategic options for US leaders that, taken together, suggest a wider range of opportunities for the United States to address an ascendant China. The first strategy is Accommodate - an effort to adapt to a new balance of power by adjusting relations with a serious competitor - in effect, making the best of unfavorable trends without resorting to military means. The second is Undermine - a strategy to foment regime change within the country, or even divide it against itself. The third is Negotiate a Long Peace - if it were negotiable, rivals could agree to take a quarter-century hiatus that imposes considerable constraints in some areas of their competition in order to focus on more urgent priorities, particularly their own domestic affairs. The fourth is Redefine the Relationship - propose a new conception of new form of great power relations.

In the conclusion chapter, Allison (2017) argues that to escape Thucydides's Trap, US leaders will need to clarify vital interests because in a struggle as epic as the one between China and the United States, US government must distinguish the vital from the vivid. He also points out the necessity of understanding what China is trying to do, namely understanding its aims, in order to be better prepared to resolve differences. Moreover, he stresses the importance of strategy and making domestic challenges central.

'Destined for War' provides, in accessible language, a comprehensive description of the impact of a rising China on the United States and the global order. It also offers an insightful and well-developed qualitative analytical framework for those keen on studying either rising 
powers, a rising China or power transition in international system. In this particular, the book innovates in comparison with the work by John Ikenberry (2008) and Randall Schweller and $\mathrm{Pu}$ (2011) about the US-China relations. On one hand, Allison (2017) dismantles Ikenberry (2008) arguments that war between China and the U.S. is unlikely because the current liberal order not only has remarkable capacity to accommodate China's rise, but also allows it to be the self-interest of the two countries to choose not go to war. On the other hand, he dismantles Schweller and Pu's argument (2011) that a counterbalancing reaction to U.S. primacy has not yet taken place and, therefore, the US-China relations still in a phase of deconcentration/delegitimation prior to military confrontation or even the threat of such conflict.

It is worth noting that the Thucydides's Trap Case File offers too small a data set (only 16 cases) to support statistically based claims about historical patterns or regularities, or for use by social scientists seeking to do so. However, this methodological limitation of the Case File has already been identified by Allison (2017) in the 'Appendix 2' of the book. In this sense, the author highlights that the Thucydides's Trap Project is a work in progress in which additions, suggestions, criticism and comments to the current Case File and for Phase II of the Project are not just invited, but also welcomed.

Despite this minor issue, the book is an essential reading for chiefs of state, military officers, diplomats, strategists, and scholars of all nations. It's also an important contribution to the body of international relations and political science work that should be added to these courses reading list in universities around the world.

\section{References}

ALLISON, Graham (2017), Destined for War: Can America and China Escape Thucydides's Trap? New York: Houghton Mifflin Harcourt. 389 pp..

IKENBERRY, G. John (2008), The rise of China and the future of the West: can the liberal system survive? Foreign Affairs. Vol. 87, № 01, pp. 23-37.

SCHWELLER, Randall L. and PU, Xiaoyu (2011), After unipolarity: China's visions of international order in an Era of U.S. decline. International Security. Vol. 36, № 01, pp. 41-72. 